\section{Your view into the Canadian Respiratory Conference - uncut}

$\mathrm{T}_{\mathrm{n}}^{\mathrm{h}}$ his is a huge year for the Canadian Thoracic Society! 2008 marks our 50th anniversary as well as the year we and our partners launched the Canadian Respiratory Conference (CRC). How fitting that our Jubilee Year would see the revival of a national respiratory meeting!

In my previous President's Page, I expressed my thoughts concerning the great benefits of holding the national CRC. I hope you had an opportunity to read those reflections and that you recognize the need for the voice of the entire respiratory community to be heard on this most important subject - a national respiratory meeting.

The organizing and program committees have received the evaluations of the first iteration of A Breath of Fresh Air, and are combing through them to glean the feedback on what worked and what needs further consideration. I would like to take this opportunity to share the feedback on the CRC, and to let you know what your colleagues had to say about this inaugural conference.

Therefore, in the present edition of the President's Page, I have chosen to step back and provide a summary of the CRC evaluations. To do so, I will present the numerical rating averages on general questions, as well as a sampling of answers to open-ended questions.

We received a total of 203 evaluations, with responses primarily from the following professional groups:

$\begin{array}{lr}\text { Respirologists } & 49 \\ \text { Respiratory therapists } & 41 \\ \text { Nurses } & 22 \\ \text { Respiratory educators } & 20 \\ \text { Physiotherapists } & 16 \\ \text { Researchers } & 14 \\ \text { Pediatric respirologists } & 7 \\ \text { Fellows } & 7\end{array}$

It is my hope that this wide distribution of the evaluation results will give rise to a strong sense of ownership of this most important conference.

This is your chance to connect with the CRC, uncut:

\section{GENERAL QUESTIONS AND RATING AVERAGES*}

- The topics were highly relevant and important. (4.35)

- The program met the stated learning objectives. (4.40)

- The program met my personal learning objectives. (4.14)

- The program met my expectations. (4.23)

\section{Votre point de vue sur le Congrès canadien sur la santé respiratoire - non censuré}

C 'est une énorme année pour la Société canadienne de thoracologie ! 2008 marque notre 50e anniversaire et l'année du lancement du Congrès canadien sur la santé respiratoire avec nos partenaires. Comme il est approprié qu'un congrès national sur la santé respiratoire renaisse l'année même de notre jubilé !

Dans la dernière page du président, je vous faisais part des grands avantages de ce congrès national. J'espère que vous avez eu l'occasion de lire ces réflexions et que vous convenez de l'importance de faire entendre toute la communauté de la santé respiratoire sur ce sujet d'importance, un congrès national sur la santé respiratoire.

Le comité d'organisation et le comité du programme ont reçu les évaluations de la première mouture d'Une bouffée d'air frais et les passent au peigne fin pour savoir ce qui a fonctionné et ce qu'il faut réévaluer. Je tiens à partager les commentaires au sujet de ce congrès inaugural et à vous transmettre ce que vos collègues avaient à dire à cet égard.

C'est pourquoi dans cette page du président, j'ai décidé de m'effacer et de résumer les évaluations du congrès. Je vous présenterai les évaluations numériques moyennes des questions d'ordre général et un échantillonnage des réponses aux questions ouvertes.

Nous avons reçu un total de 203 évaluations, et les réponses provenaient surtout des groupes professionnels suivants :

$\begin{array}{lr}\text { Pneumologues } & 49 \\ \text { Inhalothérapeutes } & 41 \\ \text { Infirmières } & 22 \\ \text { Éducateurs en santé respiratoire } & 20 \\ \text { Physiothérapeutes } & 16 \\ \text { Chercheurs } & 14 \\ \text { Pneumologues pédiatriques } & 7 \\ \text { Étudiants au postdoctorat } & 7\end{array}$

J'espère que cette vaste répartition des résultats des évaluations donnera lieu à un solide sentiment d'appartenance envers ce congrès essentiel.

C'est là votre chance de connaître le congrès, sans censure.

\section{QUESTIONS GÉNÉRALES ET MOYENNES DES ÉVALUATIONS*}

- Les sujets étaient très pertinents et importants. $(4,35)$

- Le programme a respecté les objectifs d'apprentissage établis. $(4,40)$

- Le programme a respecté mes objectifs d'apprentissage personnels. $(4,14)$ 
- The program was credible and non-biased. (4.51)

- The program did not appear to be influenced by unreported conflicts of interest. (4.55)

- The discussion was useful. (4.26)

- I gained insights as a result of the interaction with my peers. (4.23)

- This program provided insights which I will share with colleagues. (4.32)

- The program was well organized. (4.50)

- I would attend another similar conference. (4.51)

*The rating average is based on a scale of 1 (low) to 5 (high).

\section{STRENGTHS OF THE CRC}

- Canadian forum which has been lacking for many years. As a graduate, this is the first time I have had an opportunity to be in a conference that is specific to Canadian respirologists. Interactions among colleagues is key as we try to re-develop a strong national forum in pulmonary medicine

- Highly qualified speakers and well organized conference

- Information on research in Canada interesting; Now know it may be helpful to partner with universities for research funding

- Multidisciplinary attendance, multiple concurrent sessions

- Updates on smoking cessation

- Networking with other health professionals

- Seeing our colleagues

- Excellent educational program; We have outstanding/world class respirologists

- Format: Succinct, variety of presentations (as opposed to longer sessions) with multiple choices at concurrent times

- Two days, perfect length for program

- Interdisciplinary, great interacting and so many professions

- Topics covered a broad cross-section

- Pediatric respirologists all together in one place; Canadian focus

- Great opportunity to network with colleagues across the country bringing in allied health professionals

- Use of Canadian speakers

- Good use of 30 min talks (long enough without being too long)
- Le programme a respecté mes attentes. $(4,23)$

- Le programme était crédible et impartial. $(4,51)$

- Le programme ne semblait pas influencé par des conflits d'intérêts non déclarés. $(4,55)$

- Les discussions étaient utiles. $(4,26)$

- Les interactions avec les congressistes m'ont apporté de nouvelles connaissances. $(4,23)$

- Ce programme m’a apporté des connaissances que je partagerai avec mes collègues. $(4,32)$

- Le programme était bien organisé. $(4,50)$

- J'assisterais à un autre congrès similaire. $(4,51)$

*La moyenne des évaluations se fonde sur une échelle de 1 (faible) à 5 (élevé).

\section{LES POINTS FORTS DU CONGRÈS}

- Une tribune canadienne qui manquait depuis de nombreuses années. À titre de diplômé, c'est la première fois que je participe à un congrès propre aux spécialistes canadiens de la santé respiratoire. Les interactions entre collègues sont essentielles pour tenter de rétablir une tribune nationale solide en médecine pulmonaire.

- Des conférenciers hautement compétents et un congrès bien organisé.

- Information intéressante sur les recherches canadiennes. Je sais maintenant qu'il peut être utile de s'associer aux universités pour le financement de la recherche.

- Participation multidisciplinaire, multiples séances concomitantes.

- Mise à jour sur l'abandon du tabagisme.

- Réseautage avec d'autres professionnels de la santé.

- Rencontre avec des collègues.

- Excellent programme de formation. Nous comptons sur des spécialistes de la santé respiratoire remarquables/de renommée internationale.

- Structure : succincte, présentations variées (contrairement aux séances plus longues) et choix multiples de séances concomitantes.

- Deux jours, durée idéale pour le programme.

- Interdisciplinaire, excellentes interactions et beaucoup de professions.

- Les sujets couvraient de vastes thèmes transversaux.

- Les pneumologues pédiatriques tous rassemblés au même endroit; thème canadien

- Excellente occasion de réseauter avec des collègues de partout au pays, y compris les professionnels paramédicaux.

- Recours à des conférenciers canadiens. 


\section{AREAS THAT REQUIRE IMPROVEMENT}

- Cocktails in the exhibition area: entertainment provided was too loud and did not provide for a good context for meeting with customers

- More involvement and content for respirology trainees

- A content stream for the various health professionals (RN, PT, RT)

- More pediatric content

- Encourage knowledge transfer and translation topics

- Identify the various professions on badges; there were few physiotherapists and I had no way of identifying them

- Speakers spoke too quickly

- More scientific and research content

- The poster sessions weren't validated

- Since simultaneous translation was available and the conference was held in Montreal, Québec, the francophone speakers could have done their presentations in French. The official languages policy applies to French as much as to English and the interpretation can also be done from French to English

- Food: I encountered empty food trays

- More presentations by allied health for allied health

- Pediatric half-day on inflammation should be part of the program and offered either within (preferably) or as a satellite

- Friday evening social event - would prefer something more fancy/formal

- Seems difficult to blend needs of physicians and other health care professions

- Temperature control of rooms

- Have a site specific dinner meeting, eg. Hamilton or Ottawa, etc, so groups get together on Friday night to chat/socialize/network

- Cost of conference a bit high

- Timing of conference for 2009 is very close in time in relation to Better Breathing/ATS

- Seating should be provided for breaks and lunch as it is hard to carry coats, umbrellas, pamphlets and juggle coffee and food

- Relevant new research presented

- Start conference with exciting/motivating talks relevant to all

- Opportunity for more interactive sessions versus didactic

- Handouts for the programs please
- Bon usage des exposés de 30 minutes (assez longs, mais pas trop).

\section{SECTEURS À AMÉLIORER}

- Cocktail au salon des exposants : le spectacle était trop bruyant, et le contexte se prêtait mal aux rencontres avec les clients.

- Plus de participation et de contenu pour les stagiaires en santé respiratoire.

- Contenu continu pour les divers professionnels de la santé (infirmières autorisées, physiothérapeutes, inhalothérapeutes).

- Plus de contenu pédiatrique.

- Encourager les sujets en transmission du savoir.

- Indiquer les diverses professions sur les cocardes. Il y avait peu de physiothérapeutes, et je n'avais aucun moyen de les repérer.

- Les conférenciers parlaient trop vite.

- Plus de contenu scientifique et de recherche.

- Les séances par affiches n'étaient pas validées.

- Puisqu'on proposait la traduction simultanée et que le congrès avait lieu à Montréal, au Québec, les conférenciers francophones auraient pu donner leur présentation en français. La politique sur les langues officielles s'applique au français tout autant qu'à l'anglais, et il est possible d'interpréter du français vers l'anglais.

- Nourriture : J'ai trouvé des plateaux vides.

- Plus de présentations par des professionnels paramédicaux pour les professionnels paramédicaux.

- La demi-journée de pédiatrie sur l'inflammation devrait être intégrée au programme et être offerte pendant les activités (de préférence) ou sous forme de séance satellite.

- L'activité sociale du vendredi soir : J'aurais préféré quelque chose de plus chic/de plus grand apparat.

- Il semble difficile de mêler les besoins des médecins à ceux des autres professions de la santé.

- Contrôle de la température des pièces.

- Prévoir une réunion selon les provenances, p. ex., Hamilton, Ottawa, etc., afin que les groupes se réunissent le samedi soir pour discuter, socialiser ou réseauter.

- Coût du congrès un peu élevé.

- La date du congrès de 2009 est très rapprochée de celle de Better Breathing de l'ATS.

- Il faudrait prévoir des sièges lors des pauses et du dîner. Il est difficile de transporter son manteau, son parapluie, les dépliants tout en jonglant avec le café et la nourriture.

- Présenter de nouvelles recherches pertinentes. 
- Availability of presentations on line

- More pediatric representation

- Opening Plenary needs to be more upbeat with a topic that touches everyone

- Please choose physicians to speak that respect questions and opinions from non-physicians

- Too expensive for researchers and students; this may limit future attendance

- More or better research - less clinical emphasis or more parallel sessions

- Two hours is too long to sit - stand up breaks; a room change might help but would slow program

- Posters not visible - not enough time to see them all

- Decrease the number of presentations each day (7:15 am to $5 \mathrm{pm}$ is long!!!)

- Friday night social event was not easy to hear in all areas of the room, interaction with colleagues was very difficult and food was not at all worth the price of entry...it's Montreal - there are TONS of wonderful places to eat!

- Better exhibits. More exhibitors with new equipment

- Small group sessions - ie, lunch tutorials

- Topics of no interest for everyone (research) should be offered as concurrent sessions

- Date!!! The end of June is a very busy time for most of us who are parents! End of school presentations, rehearsals, concerts. Lots of sacrifices to be here. Perhaps earlier June or May next time

- The 7:00 am talks were great but do we need to start so early?

- We should try to attract nonphysicians (asthma educators, RT's, etc). We need another 'stream' to do this. If this is to be done, we would need representatives of those organizations on the planning committee. I find conferences like this type (ATS or the Alberta

Respiratory Disease Symposium) bring all experts together, not just physicians and improve overall communication and messaging more than a meeting directed primarily to physicians

Not bad for a first try! I have sought to be as unbiased as possible in selecting the comments listed in this overview. The choice of this final comment, however, is quite biased indeed:

"Please do it again!”

We will.

See you at A Breath of Fresh Air 2009!
- Commencer le congrès par une allocution passionnante ou de motivation pertinente pour tous.

- Plus de séances interactives par rapport aux séances didactiques.

- Prière de remettre de la documentation sur le programme.

- Accès aux présentations par voie électronique.

- Plus de présentations pédiatriques.

- La plénière d'ouverture doit être plus dynamique et porter sur un sujet qui touche tout le monde.

- Veuillez choisir des médecins conférenciers qui respectent les questions et les avis des non-médecins.

- Trop cher pour les chercheurs et les étudiants, ce qui risque de limiter la future participation.

- Plus de recherches ou meilleures recherches - moins d'importance à la clinique ou plus de séances parallèles.

- Deux heures, c'est trop long pour rester assis. Pauses debout. Un changement de salle pourrait être utile, mais le programme s'en verrait ralenti.

- Affiches non visibles, pas assez de temps pour toutes les voir.

- Réduire le nombre de présentations par jour (de 7 h 15 à 17 h, c'est long !!!)

- Il n'était pas facile d'entendre l'activité sociale du vendredi soir partout dans la pièce; il était très difficile de converser avec les collègues et le repas ne valait pas le prix d'entrée... C'est Montréal, il y a des TONNES de merveilleux endroits pour manger!

- Meilleurs exposants. Plus d'exposants présentant du nouveau matériel.

- Séances en petits groupes, p. ex., débats dirigés pendant le dîner.

- Les sujets qui n'intéressent pas tout le monde (p. ex., recherche) devraient être présentés dans le cadre de séances concomitantes.

- La date !!! La fin de juin est une période très achalandée pour la plupart des parents ! Présentations de fin d'années, répétitions, concerts. Beaucoup de sacrifices pour venir ici. Peut-être plus tôt en juin ou en mai la prochaine fois.

- Les allocutions à $7 \mathrm{~h}$ étaient excellentes, mais est-il nécessaire de commencer si tôt ?

- Nous devrions essayer d'attirer des non-médecins (éducateurs sur l'asthme, inhalothérapeutes, etc.) Nous avons besoin d'un autre « volet » pour y parvenir. Pour ce faire, nous aurions besoin de représentants de ces organismes au comité de planification. Je trouve que les congrès de ce genre (ATS ou Alberta Respiratory Disease Symposium) rassemblent tous les experts, pas seulement 
Canadian Respiratory Conference

April 23 to 25, 2009

Westin Harbour Castle

Toronto, Ontario

Respectfully submitted,

Robert D Levy MD FRCPC

President, Canadian Thoracic Society des médecins, ce qui améliore les communications et les messages globaux davantage qu'un congrès axé seulement sur les médecins.

Pas trop mal pour un premier essai ! J'ai essayé d'être le plus impartial possible dans la sélection des commentaires. Le choix de ce dernier commentaire, cependant, est tout à fait partial :

«S'il vous plaît, recommencez!»

C'est ce que nous ferons.

Au plaisir de vous voir à Une bouffée d'air frais 2009!

Congrès canadien sur la santé respiratoire

Du 23 au 25 avril 2009

Westin Harbour Castle

Toronto (Ontario)

Amicalement,

Robert D Levy MD FRCPC

Président, Société canadienne de thoracologie

The Canadian Thoracic Society thanks Medigas for an unrestricted educational grant supporting the distribution of the Recommendations for the Diagnosis and Treatment of Sleep Apnea (brochure) in this edition of the Canadian Respiratory Journal.

La Société canadienne de thoracologie remercie Medigas de lui avoir versé une subvention d'éducation sans restrictions en appui à la distribution du dépliant intitulé Recommandations pour le diagnostic et le traitement de l'apnée du sommeil dans le présent numéro de la Revue canadienne de pneumologie. 


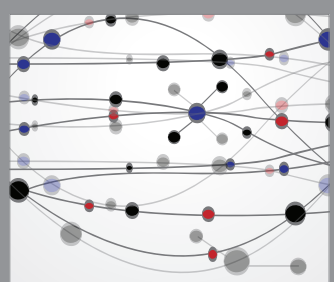

The Scientific World Journal
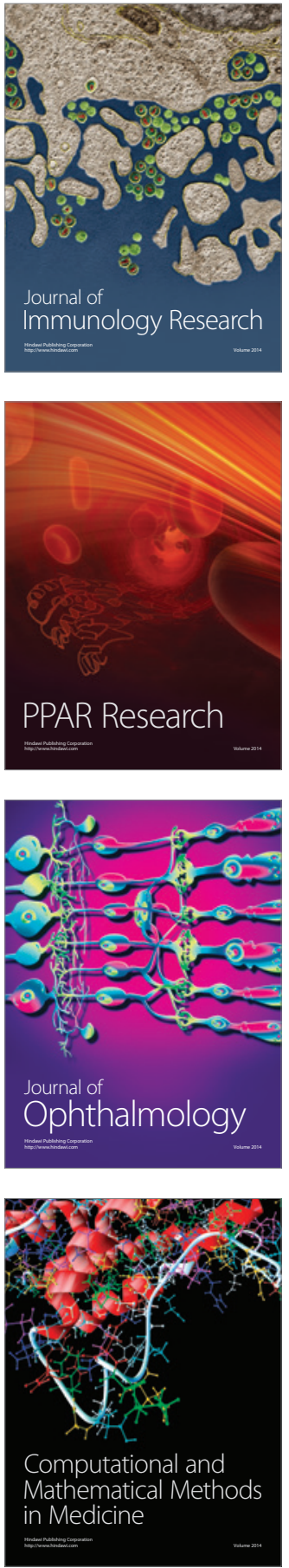

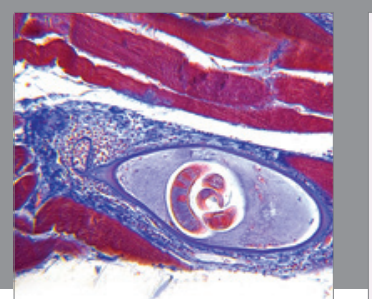

Gastroenterology Research and Practice

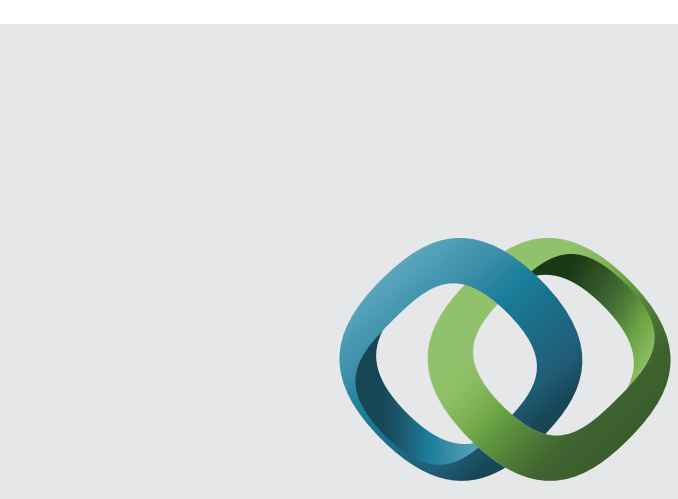

\section{Hindawi}

Submit your manuscripts at

http://www.hindawi.com
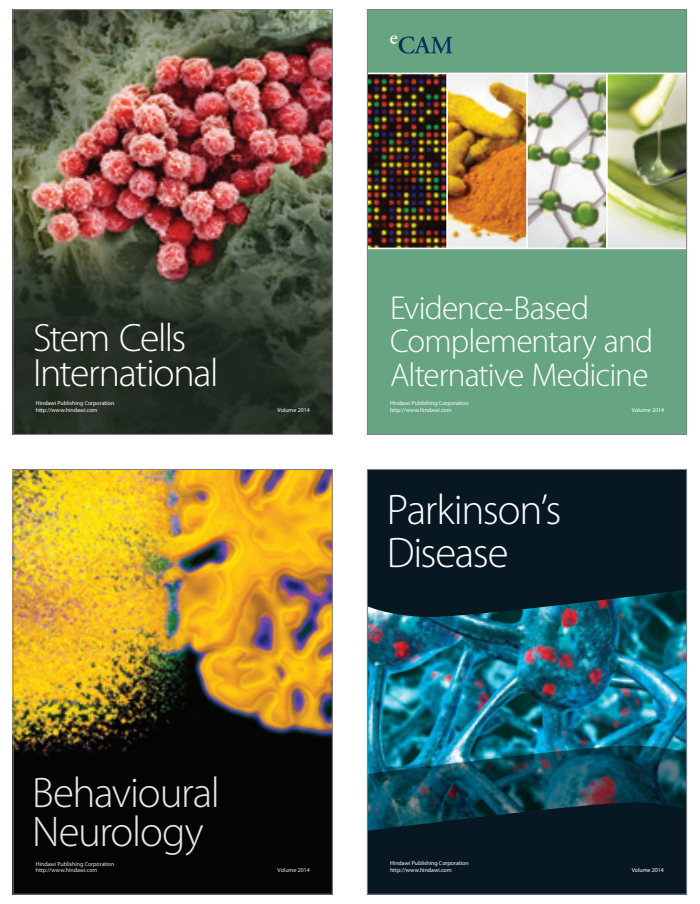
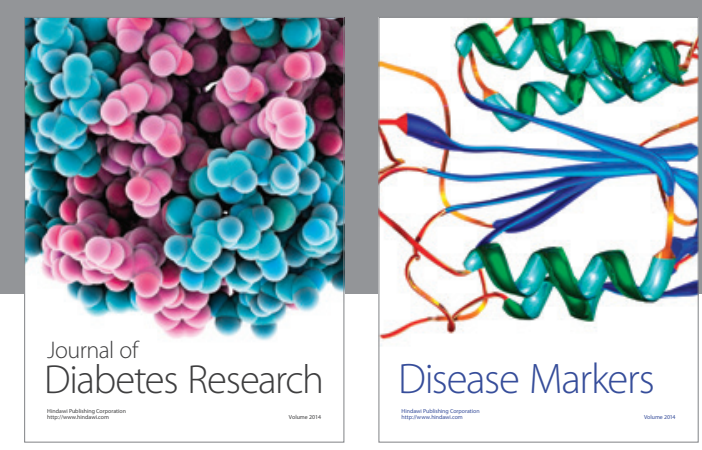

Disease Markers
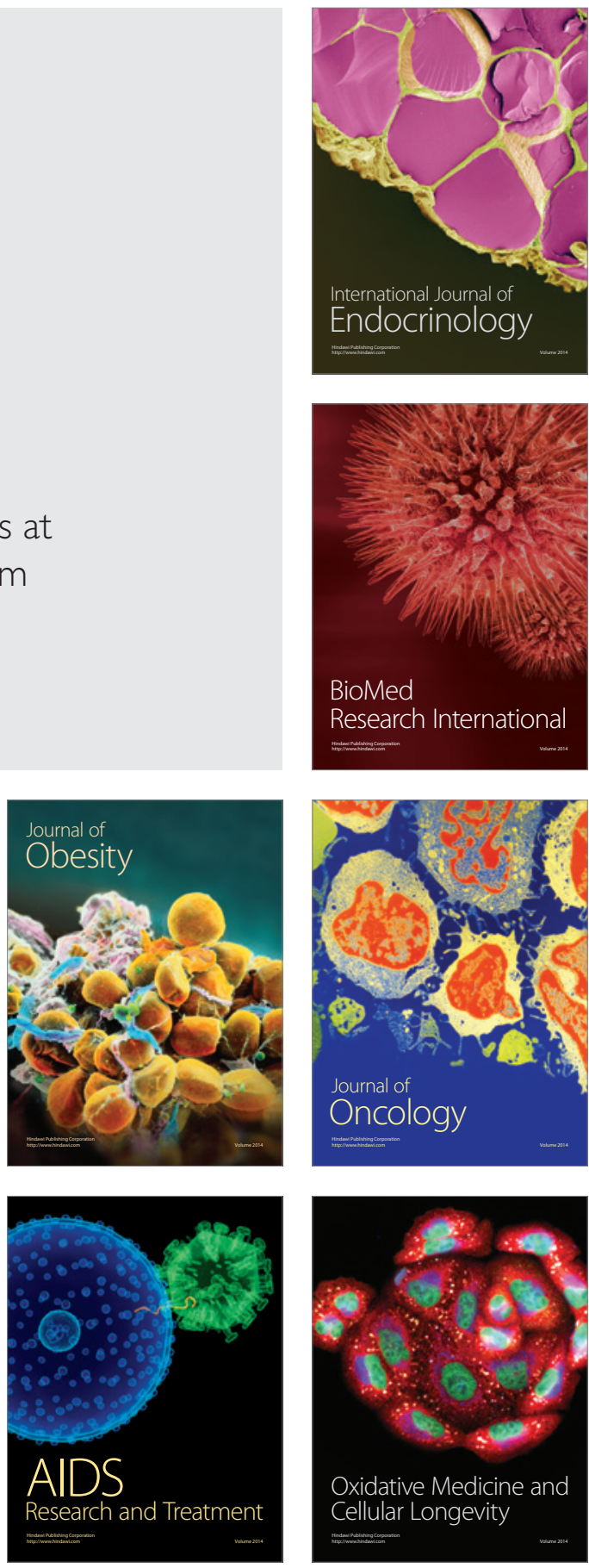